\title{
FINANCIAL FEASIBILITY OF PURSE SEINE FISHERIES IN BALIMU VILLAGE, SOUTH LASALIMU OF BUTON REGENCY
}

\author{
Abdul Sarifin $^{1}$. Azwar Sidiq ${ }^{1}$. Wa Ode Harliyanti Unga ${ }^{2}$. \\ Aminur $^{3}$
}

Ringkasan Purse siene fishery is a capitalintensive and labor-intensive business, but it carries considerable business risk due to climate change, increased operating costs, decreased fish stocks and unstable fish prices. The purpose of this study was to determine the financial feasibility of a purse seine fishery business in Buton Waters. This research was conducted in October 2020 in Balimu Village, South Lasalimu District, Buton Regency, Southeast Sulawesi Province. This study used a survey method using a questionnaire. Data were analyzed descriptively quantitative. The results showed that the average amount of profit earned during the peak fishing season was IDR 277,263,939/ month. The NPV value is IDR 4,021,035,338 $(>0)$, the Net B / C Ratio value is 6.63 (>1), the $R / C$ Ratio value is 6.10 (> 1), the IRR value is 2.87 ( $>15 \%$ interest rate), the payback period is 8 months and 5 days, and the ROI value is

1) Jurusan Agrobinis Perikanan Fakultas Perikanan dan Ilmu Kelautan Universitas Halu Oleo ${ }^{2}$ ) Jurusan Manajemen Keungan Fakultas Ilmu Sosial dan Ilmu Politik Universitas Halu Oleo $2^{3}$ ) Jurusan Teknik Mesin Fakultas Teknik, Universitas Halu Oleo J1. HEA. Mokodompit Kampus Hijau Bumi Tridharma Kendari 93231 Indonesia

E-mail: abdulsarifin@gmail.com
2.31\%. Thus, purse seine fishery activities in Balimu Village, South Lasalimu Subdistrict during the peak fishing season are financially feasible.

Keywords Purse Seine, Income, Financial Feasibility, Buton

\section{PENDAHULUAN}

Sektor perikanan memiliki peranan penting dalam menopang kesejahteraan masyarakat dan mendorong pertumbuhan ekonomi bagi daerah. Dilihat dari potensinya, secara spasial wilayah perairan laut lebih luas dibandingkan wilayah daratan. Namun demikian potensi yang besar tersebut tidak serta merta menjadikan masyarakat khususnya nelayan memiliki kesejahteraan yang lebih baik. Berdasarkan data BPS Indonesia, pada tahun 2019 tercatat jumlah penduduk miskin di Indonesia pada bulan Maret sebanyak 25,14 juta orang. Berbagai macam faktor internal dan eksternal yang dapat menyebabkan kemiskinan pada nelayan antara lain tingkat pendidikan yang rendah, pola hidup, pengelolaan keuangan keluarga, kepemilikan dan akses terhadap permodalan 
yang terbatas, dan adopsi teknologi yang rendah. Sementara itu faktor lain yang dapat menyebabkan adalah kualitas lingkungan laut yang terus menurun dan cuaca yang semakin ekstrim.

Usaha perikanan tangkap menggunakan alat tangkap purse seine di Kabupaten Buton suda cukup lama dilakukan. Alat tangkap ini termasuk alat tangkap yang memiliki peluang yang besar untuk dikembangkan mengingat kapasitas tangkap yang cukup besar. Namun demikian tidak menutup kemungkinan justru usaha tersebut dapat berakibat pada kerugian mengingat biaya investasi alat tangkap ini cukup besar, keadaan cuaca yang tidak menentu, biaya operasional yang semakin meningkat, upaya penangkapan yang bertambah, dan hasil tangkapan yang berkurang.

Berdasarkan data Sekunder Dinas Kelautan dan Perikanan Provinsi Sulawesi Tenggara tahun 2020, produksi perikanan tangkap Kabupaten Buton tahun 2015 adalah sebesar 22,008 ton, tahun 2016 sebesar 24.343 ton, tahun 2017 sebesar 26.382 ton, tahun 2018 sebesar 29.116 ton dan pada 2019 sebesar 26.908 ton. Berdasarkan data tersebut bahwasanya terjadi penurunan produksi perikanan tangkap pada tahun 2019. Jumlah nelayan Kabupaten Buton pada tahun 2019 mencapai 10.045 orang mengalami peningkatan $15,23 \%$ dari tahun sebelumnya. Peningkatan jumlah nelayan diikuti dengan peningkatan jumlah armada penangkapan dari 3.592 unit tahun 2018 menjadi 4.286 tahun 2019 atau terjadi kenaikan sebesar 19,25\%. Peningkatan jumlah armada dan nelayan, berakibat meningkatkan jumlah alat tangkap sebesar 2,13\% pada tahun 2019. Komposisi armada penangkapan terdi- ri dari 26 unit kapal dengan kapasitas 10 - 20 GT, 13 unit dengan kapasitas 20-30 GT, dan 1 unit kapal dengan kapasitas 30-50 GT.

Salah satu Kecamatan yang merupakan kawasan kegiatan perikanan tangkap di Kabupaten Buton adalah Kecamatan Lasalimu Selatan. Berdasarkan data Dinas Perikanan Kabupaten Buton (2020), jumlah produksi perikanan tangkap untuk kecamatan Lasalimu Selatan pada tahun 2019 mencapai 4.229,30 ton, atau sebesar $15,72 \%$ dari 6 kecamatan yang lainnya. Alat tangkap purse seine merupakan salah satu alat tangkap yang dioperasikan oleh nelayannelayan di daerah tersebut. Desa Balimu merupakan desa yang berada dalam wilayah administrasi Kecamatan Lasalimu Selatan sebagai salah satu pusat kegiatan nelayan. Desa Balimu memiliki pelabuhan rakyat yang sekaligus digunakan sebagai tempat pendaratan ikan-ikan hasil tangkapan nelayan purse seine yang ada disekitarnya.

Lokasi penangkapan nelayan purse seine di daerah ini cukup dekat, berada disekitar perairan laut banda, Teluk Buton, Perairan Kabupaten Buton Utara (Ereke), dan disekitar perairan Kabupaten Wakatobi. Dari pesisir Desa Balimu masih dapat terlihat jelas beberapa rumpon-rumpon yang ditempatkan oleh nelayan. Satu trip penangkapan biasanya hanya dilakukan dalam satu hari. Nelayan meninggalkan pelabuahan rakyat menuju lokasi tangkap pada sore hari dan kembali untuk mendaratkan hasil tangkapan pagi hari sampai menjelang siang. Penggunaan biaya operasiaonal penangkapan yang rendah dapat tercapai mengingat lokasi penangkapan yang cukup dekat. Menurut Winardi (1998) sebagai suatu unit 
ekonomi yang melakukan suatu usaha, tentunya tidak terlepas dari prinsip-prinsp usaha pada umumnya, dimana semua tindakan yang dilakukan hendaknya dipertimbangkan dan diperhitungkan dengan matang antara biaya yang akan dikeluarkan dengan keuntungan yang akan diperoleh. Sesuai dengan prinsip ekonomi yaitu dengan mengeluarkan modal atau biaya yang sekecil-kecilnya untuk mendaptkan keuntungan yang sebesarbesarnya.

Berangkat dari gambaran tersebut di atas, maka penelitian ini dilakukan dengan tujuan untuk mengetahui kelayakan finansial dari kegiatan penangkapan nelayan purse seine di Desa Balimu Kecamatan lasalimu Selatan Kabupaten Buton Provinsi Sulawesi Tenggara.

\section{MATERI DAN METODE}

Penelitian ini dilaksanakan pada bulan Oktober tahun 2020 di Desa Balimu Kecamatan Lasalimu Selatan Kabupaten Buton Provinsi Sulawesi Tenggara. Lokasi penelitian ditentukan secara sengaja (purposive) berdasarkan keberadaan nelayan-nelayan purse seine di Desa Balimu Kecamatan Lasalimu Selatan. Lokasi ini dipilih karena merupakan salah satu sentra kegiatan perikanan dengan tipologi perikanan tangkap khususnya purse seine. Arikunto (2010) menjelaskan bahwa purposive sampling dilakukan dengan cara mengambil subjek bukan didasarkan atas strata, random atau daerah tetapi didasarkan atas adanya tujuan tertentu. Peta lokasi penelitian dapat dilihat pada Gambar 1 .

Untuk menentukan responden/sampel pada populasi dilakukan dengan meto-

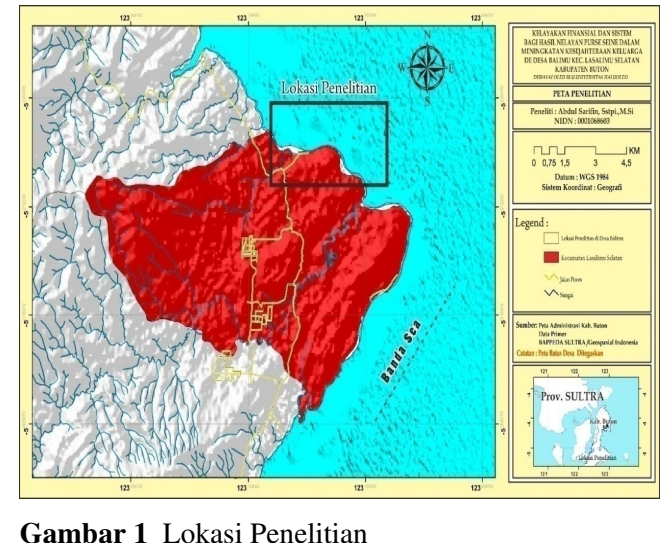

Gambar 1 Lokasi Penelitian

de simple random sampling (acak sederhana). Menurut Sugiyono (2001) teknik simple random sampling adalah teknik pengambilan sampel dari anggota populasi yang dilakukan secara acak tanpa memperhatikan strata yang ada dalam populasi itu.Untuk menentukan banyaknya sampel dari populasi pada peneltian ini, menggunakan rumus Slovin yang dikemukakan oleh Umar (2013).

$n=\frac{N}{1+n e^{e}}$

dimana: $\mathrm{n}=$ ukuran sampel, $\mathrm{N}=$ ukuran populasi, dan $\mathrm{e}=$ batas toleransi kesalahan; Populasi dalam penelitian ini adalah 18 orang sehinga dengan tarap kepercayaan $75 \%$ atau $e=25 \%$, maka diperoleh sampel atau responden sebanyak 8 orang

Teknik pengumpulan data dalam penelitian ini dilaksanakan dengan : a) Observasi, yakni teknik pengumpulan data dengan melakukan pengamatan langsung terhadap objek penelitan. b) Kuisioner, yakni tehnik pengumpulan data dengan mengajukan daftar pertanyaan kepada responden yang telah disusun secara terstruktur sebelumnya. c) Wawancara, yakni tehnik pengumpulan data yang dilakukan secara terbuka tanpa daftar pertanyaan yang meng- 
ikat, tetapi tetap mengarah pada informasi yang dibutuhkan dalam penelitian. d) Dokumentasi, yakni tehnik pengumpulan data melalui pengambilan gambar guna membantu dalam visualisasi kegiatan penelitian.

Analisis data dalam penelitian ini menggunakan analisis kuantitatif, sedangkan untuk menjelaskan nilai-nilai yang dihasilkan dilakukan dengan metode deskriptif kuantitatif. Penelitian dekriptif kuantitatif merupakan penelitian yang bertujuan menjelaskan fenomena yang ada dengan menggunakan angka-angka untuk menggabarkan karakteristik individu atau kelompok (Syamsuddin and Damayanti, 2011). Analisis data yang dilakukan pada penelitian ini yang terdiri dari analisis penerimaan, keuntungan, payback period $(\mathrm{PbP})$, return of investment (ROI), Net present value (NPV), Net benefit-cost ratio $(\mathrm{Net} \mathrm{B} / \mathrm{C})$, dan Internal rate of return (IRR).

Biaya Produksi adalah seluruh biaya yang yang dikeluarkan oleh nelayan selama proses produksi yang terdiri dari biaya tetap dan biaya variabel. Biaya total merupakan penjumlahan biaya tetap dan biaya variabel perusahaan. Secara matematis, rumus untuk menghitung biaya total adalah (Rahardja and Manurung, 2008).

$T C=T F C+T V C$

dimana, $\mathrm{TC}=$ Biaya total $(\mathrm{Rp}) \mathrm{TFC}=$ Total biaya tetap (Rp), yaitu merupakan biaya produksi yang jumlahnya tetap dan tidak terpengaruh dengan jumlah produk yang diproduksi oleh perusahaan. TVC $=$ Total biaya variabel $(\mathrm{Rp})$, yaitu merupakan biaya produksi yang jumlahnya berubah - ubah mengikuti jumlah produk yang diproduksi oleh perusahaan.
Analisis penerimaan bertujuan untuk mengetahui seberapa besar penerimaan yang diperoleh nelayan purse seine dari hasil kegiatnnya. Analisis ini belum melibatkan besaran biaya-biaya yang digunakan. Rumus untuk mengetahui tingkat penerimaan menggunakan rumus menurut Rahardja dan Manurung, (2008)

$T R=P \cdot Q$

dimana, $\mathrm{TR}=$ Total Penerimaan $/$ Total Revenue $(\mathrm{Rp}) ; \mathrm{P}=\operatorname{Harga}(\mathrm{Rp}) ; \operatorname{dan} \mathrm{Q}=$ Quantitas/Hasil Produksi; Dengan kriteria: TR > TC : Usaha menguntungkan; TR $=$ TC $:$ Usaha pada titik keseimbangan (titik impas); dan TR $<$ TC : Usaha mengalami kerugian

Analisis keuntungan bertujuan untuk mengetahui besarnya keuntungan yang diperoleh neleyan purse seine dari aktivitas yang dilakukan setelah dikurangi seluruh biaya yang digunakan. Rumus keuntungan sebagai berikut (Rahardja and Manurung, 2008).

$\pi=T R-T C$

dimana, $\pi=$ keuntungan $(\mathrm{Rp})$

Analisis imbangan penerimaan dan biaya ini bertujuan untuk mengetahui seberapa jauh setiap nilai rupiah biaya yang digunakan dalam kegiatan usaha/proyek dapat memberikan sejumlah nilai penerimaan sebagai manfaatnya. Rumus yang digunakan menghitung R/C Ratio yaitu (Kadariah and Gray, 1999)

$R / C=\frac{T R}{T C}$

dimana, $\mathrm{R} / \mathrm{C}=$ Rasio perimbangan penerimaan dan biaya; dengan kriteria $\mathrm{R} / \mathrm{C}$ $>1$, usaha/proyek menguntungkan, $\mathrm{R} / \mathrm{C}$ 
$<1$, usaha/proyek rugi, $\mathrm{R} / \mathrm{C}=1$, usaha/proyek impas

Menurut Umar (2013) Payback peri$o d$ adalah suatu periode yang diperlukan untuk menutup kembali pengeluaran investasi dengan menggunakan aliran kas. Payback period sebagai rasio antara pengeluaran investasi dengan keuntungannya yang hasilnya dengan satuan waktu.

$P P=\frac{\text { Nilai investasi }}{\text { keuntungan }} x 1$ tahun

Return of investment (ROI) adalah kemampuan dari modal yang diinvestasikan dalam keseluruhan aktiva usaha untuk menghasilkan keuntungan bersih. Rumus yang digunakan untuk menghitung ROI adalah. Net present value digunakan untuk menilai manfaat investasi, yaitu berapa nilai kini (present value) dari manfaat bersih proyek/usaha yang dinyatakan dalam Rupiah. Net benefitcost ratio $(\mathrm{Net} \mathrm{B} / \mathrm{C})$ adalah perbandingan antara jumlah kini (present value to$t a l)$ dari keuntungan bersih pada tahuntahun dimana keuntungan bersih bernilai positif dengan keuntungan bersih yang bernilai negatif (Kadariah and Gray, 1999).

$$
\begin{aligned}
& R O I=\frac{\text { Keuntungan }}{\text { Investasi }} \times 100 \% \\
& N P V=\sum_{t=1}^{n} \frac{B_{t}-C_{t}}{(1+i)} \\
& N e t \frac{B}{C}=\frac{\sum_{t=1}^{n} \frac{B_{t}-C_{t}}{1+i}\left(B_{t}-C_{t}\right)>0}{\sum_{t=1}^{n} \frac{B_{t}-C_{t}}{1+i}\left(B_{t}-C_{t}\right)<0}
\end{aligned}
$$

dimana, $\mathrm{Bt}=$ Keuntungan dari suatu usaha pada tahun ke-t; $\mathrm{Ct}=$ Biaya produksi pada tahun ke-t; $\mathrm{i}=$ Tingkat su$\mathrm{ku}$ bunga yang berlaku; dan $\mathrm{t}=$ Umur teknis usaha; dengan kriteria : NPV >
0, Usaha dinyatakan layak untuk dilanjutkan NPV $=0$, Usaha hanya kembali modal NPV $<0$, Usaha dinyatakan layak untuk dilanjutkan. Jika B/C $>1$, berarti usaha layak dijalankan; jika $\mathrm{B} / \mathrm{C}=1$, berarti usaha impas, keputusan pelaksanaan tergantung pada investor; dan Jika $\mathrm{B} / \mathrm{C}<1$, berarti usaha tidak layak dijalankan.

Internal rate of return adalah nilai tingkat suku bunga i yang membuat NPV dari usaha sama dengan nol. IRR dapat diartikan sebagai tingkat suku bunga dimana nilai kini dari biaya total sama dengan nilai kini dari penerimaan total. IRR juga dianggap sebagai tingkat keuntungan bersih atas investasi, dimana benefit bersih yang positif ditanam kembali pada tahun berikutnya dan mendapatkan tingkat keuntungan yang sama dan diberi bunga selama sisa umur usaha.

$I R R=i_{1}+\frac{N P V_{1}}{N P V_{1}-N P V_{2}}\left(i_{1}-i_{2}\right)$

dengan $; \mathrm{NPV}_{1}=$ NPV yang masih positif; $\mathrm{NPV}_{2}=\mathrm{NPV}$ yang negatif; $\mathrm{i}_{1}=$ discount rate yang masih memberi NPV positif; $i_{2}=$ discount rate yang masih memberi NPV negatif. Sementara, jika IRR > tingkat bunga berlaku, maka proyek/usaha dinyatakan layak dan jika IRR < tingkat bunga berlaku, maka proyek/usaha dinyatakan tidak layak.

\section{HASIL DAN PEMBAHASAN}

Kecamatan Lasalimu Selatan terletak antara $123^{\circ} 0^{\prime}-123^{\circ} 13^{\prime}$ BT dan antara $5^{\circ} 14^{\prime}-{ }^{\circ} 21^{\prime} 8^{\prime}$ LS yang berada di sebagian kecil daratan Pulau Buton. Batas wilayah Kecamatan Lasalimu Selatan adalah sebagai berikut : 
Tabel 1 Karakteristik berdasarkan pendidikan Pendidikan Jumlah (Orang) Presentase (\%)

\begin{tabular}{ccc}
\hline Pendidikan & Jumlah (Orang) & Presentase (\%) \\
\hline SD & 6 & $75 \%$ \\
SMP & 1 & $13 \%$ \\
Tidak Sekolah & 1 & $13 \%$ \\
Jumlah & 8 & $100 \%$ \\
\hline
\end{tabular}

- Sebelah Utara berbatasan dengan Kecamatan Lasalimu dan Laut Banda

- Sebelah Selatan berbatasan dengan Kecamatan Siotapina dan Laut Banda

- Sebelah Timur berbatasan dengan Laut Banda

- Sebelah Barat berbatasan dengan Kecamatan Lasalimu dan Kecamatan Siotapina.

Karakteristik yang digunakan untuk mengetahui keberagaman responden nelayan Desa Balimu Kecamatan Lasalimu Selatan meliputi pendidikan terakhir, umur, pekerjaan dan pengalaman kerja. Hal ini diharapkan dapat memberikan gambaran umum terkait responden yang digunakan dalam penelitian ini. Berdasarkan Tabel 1 menunjukkan bahwa responden dengan tingkat pendidikan SD berjumlah 6 orang dengan presentase sebesar $75 \%$, tingkat pendidikan SMP berjumlah 1 orang dengan presentase $13 \%$ dan tidak sekolah berjumlah 1 orang dengan presentase sebesar 13\%. Dengan demikian sebagian besar responden memiliki tingkat pendidikan SD.

Sebagian besar responden dalam penelitian ini termasuk termasuk dalam ketegori umur produktif (berkisar 15-64 tahun). Berdasarkan Tabel 2 terlihat bahwa responden dengan rentang umur antara 26 - 35 tahun sebanyak 2 orang dengan presentase sebesar $25 \%$, umur 36-45 tahun berjumlah 3 orang dengan presentase sebesar 37\%, umur 46-55 tahun berjumlah 2 orang dengan presen-
Tabel 2 Karakteristik responden berdasarkan umur

\begin{tabular}{ccc}
\hline Umur (Tahun) & Jumlah (Orang) & Presentase (\%) \\
\hline $16-25$ & 0 & $0 \%$ \\
$26-35$ & 2 & $25 \%$ \\
$36-45$ & 3 & $37 \%$ \\
$46-55$ & 2 & $25 \%$ \\
$56-65$ & 0 & $0 \%$ \\
$66-75$ & 1 & $13 \%$ \\
Jumlah & 8 & $100 \%$ \\
\hline
\end{tabular}

Tabel 3 Karakteristik Responden berdasarkan pengalaman usaha

\begin{tabular}{ccc}
\hline Pengalaman (Tahun) & Jumlah (Orang) & Presentase (\%) \\
\hline $0-5$ & 4 & $50 \%$ \\
15-Jun & 2 & $25 \%$ \\
15 keatas & 2 & $25 \%$ \\
Jumlah & 8 & $100 \%$ \\
\hline
\end{tabular}

tase sebesar 25\%, umur 66-75 tahun sebanyak 1 orang dengan presentase sebesar $13 \%$, dengan umur rata-rata responden berusia 46 tahun.

Berdasarkan Tabel 3 menunjukan bahwa pengalaman respoden antara 0 - 5 tahun sebanyak 4 orang dengan presentase sebesar 50\%, 6 - 15 tahun berjumlah 2 orang dengan presentase $25 \%$, dan 15 tahun keatas berjumlah 2 orang dengan presentase sebesar $25 \%$. Rata-rata pengalaman usaha penangkapan nelayan yakni 14 tahun dengan kategori cukup berpengalaman.

Jumlah trip penangkapan pada musim puncak antara 15 sampai 23 trip/bulan , musim sedang antara 7 sampai 11 trip/ bulan dan musim paceklik antara 4 sampai 6 trip/bulan. Artinya bahwa kegiatan penangkapan yang dilakukan hampir sepanjang tahun. Penyebutan musim tangkap lebih dipengaruhi oleh ketidak mampuan nelayan untuk melakukan operasi penangkapan disebabkan oleh cuaca yakni angin dan gelombang pada musim timur (bulan Juni sampai September). Lokasi tangkapan yang cukup dekat mendorong nelayan untuk tetap melaut walaupun dimusim paceklik dengan tetap mempertimbangkan kesela- 
Tabel 4 Komponen investasi usaha perikanan tangkap purse seine di Desa Balimu Uraian Rata-rata Biaya (Rp)

\begin{tabular}{lr}
\hline Uraian & Rata-rata Biaya (Rp) \\
\hline Kapal & 356.250 .000 \\
Mesin Utama & 77.375 .000 \\
mesin gardan & 10.125 .000 \\
Jangkar + tali & 2.011 .111 \\
bodi batang & 3.666 .667 \\
ember & 335 \\
genset & 8.400 .000 \\
alat tangkap & 196.250 .000 \\
Rumpon & 55.125 .000 \\
GPS & 5.000 .000 \\
Jumlah & 714.789 .167 \\
\hline
\end{tabular}

matan kegiatan penangkapan. Lokasi penangkapan berada disekitar perairan laut banda, teluk buton dan Ereke, sampai wilayah Wakatobi, bahkan rumponrumpon nelayan masih terlihat dari Desa Balimu. Aktivitas penangkapan ratarata dilakukan satu hari saja (one day fishing) yakni berangkat sore hari dan pulang pagi hari. Kapasitas kapal yang digunakan cukup berpariasi yakni dari 15 sampai 30 gross ton (GT). Lokasi tangkap yang dekat penggunaan biaya yang tidak banyak, sehingga diharapkan akan mendatangkan keuntungan yang besar.

Sebuah usaha dikatakan layak secara ekonomi jika mendatangkan keuntungan yang maksimum dari kegiatan yang dilakukan. Usaha perikanan tangkap purse seine bisa dikatakan usaha yang membutuhkan modal awal yang tidak sedikit. Komponen Investasi dalam usaha perikanan tangkap purse seine di Desa Balimu Kecamatan Lasalimu Selatan dapat dilihat pada Tabel 4.

Tabel 4 menunjukkan rata investasi usaha penangkapan nelayan purse seine adalah Rp 714.789.167 dengan komponen rata-rata investasi unit kapal sebesar Rp 356.250.000, mesin utama Rp 77.375.000, mesin gardan $\mathrm{Rp} 10.125 .000$, jangkar dan tali Rp 2.011.111, bodi batang/perahu

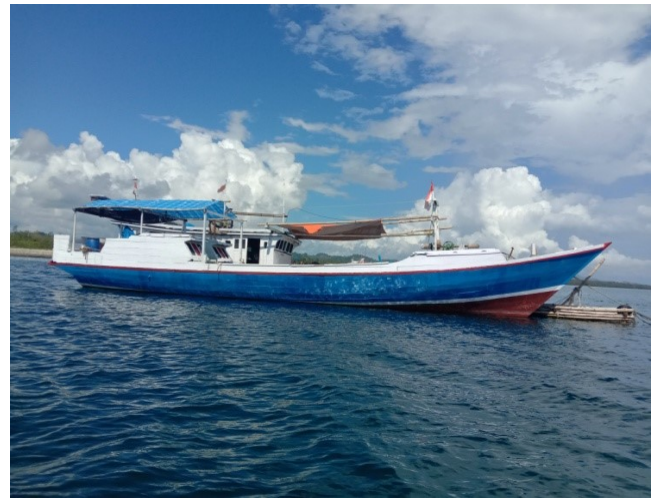

Gambar 2 Kapal purse seine di Desa Balimu

Tabel 5 Komponen baiaya tetap usaha perikanan tangkap purse seine di Desa Balimu

\begin{tabular}{lr}
\hline Uraian & Rata-rata Biaya $(\mathrm{Rp} / \mathrm{b} / \mathrm{n})$ \\
\hline Biaya Penyusutan & 1.868 .924 \\
Biaya Perawatan & 1.000 .000 \\
Biaya Perizinan & 250 \\
Jumlah & 6.118 .924 \\
\hline
\end{tabular}

Rp 3.666.667, ember Rp 335.000, genset/dinamo Rp 8.400.000, alat tangkap Rp 196.250.000, rumpon Rp 55.125.000, dan GPS Rp 5.000.000. Investasi tersebut merupakan modal sendiri nelayan, bukan modal pinjaman dari lembaga keuangan.

Keuntungan nelayan sangat ditentukan oleh alokasi biaya-biaya yang dikeluarkan dalam usaha tersebut. Biayabiaya dalam usaha perikanan tangkap purse seine meliputi biaya biaya tetap dan biaya variabel. Komponenen dalam biaya tetap itu sendiri yakni biaya penyusutan/depresiasi dari modal investasi, biaya perawatan, dan biaya perizinan. Berikut adalah komponen biaya tetap dalam usaha perikanan tangkap nelayan purse seine di Desa Balimu Kecamatan Lasalimu Selatan dalam Tabel 5.

Berdasarlan Tabel 5 terlihat bahwa ratarata biaya tetap dari depresiasi investasi adalah Rp 1.868.924/bulan, biaya perawatan Rp 1.000.000/bulan dan biaya perizinan $\mathrm{Rp} 250.000$ /bulan. Biaya depresiasi diperoleh dari nilai in- 
Tabel 6 Komponen biaya variabel usaha perikanan tangkap purse seine di Desa Balimu

\begin{tabular}{lr}
\hline Komponen biaya & Rata-rata Biaya (Rp/bln) \\
\hline BBM & 16.424 .375 \\
Oli mesin & 531.25 \\
Es & 26.400 .000 \\
Konsumsi & 7.000 .000 \\
Jumlah & 50.355 .625 \\
\hline
\end{tabular}

veastasi masing-masing dibagi dengan umur teknis peralatan investasi tersebut, sedangkan biaya perawatan adalah biaya perbaikan seperti pengecatan dan perawatan mesin dan alat tangkap. Sedangkan biaya perizinan meliputi biaya retribusi dan pengurusan suratsurat kelengkapan berlayar dan operasi penangkapan dari dinas Perhubungan dan Dinas Perikanan Provinsi.

Biaya variabel merupakan biaya operasional yang dikeluarkan oleh nelayan dalam kegiatan penangkapan persatuan waktu. Biaya operasional nelayan purse seine di Desa Balimu Kecamatan Lasalimu Selatan antara lain biaya untuk pembelian BBM, oli mesin, Es, dan Kosumsi seperti yang dapat dilihat pada Tabel 6. Tabel 6 menunjukkan bahwa jumlah biaya operasional penangkapan nelayan adalah Rp 50.355.625 /bulan, dengan komponen biaya operasional yang paling besar adalah kebutuhan bahan pengawet berupa Es Rp 26.400 .000 /bulan. kebutuhan biaya untuk BBM yakni Rp 16.424.375/bulan, oli mesin Rp 531.250 /bulan dan kebutuhan konsumsi Rp 7.000.000/bulan. Nelayan menyadari bahwa harga ikan sangat ditentukan oleh kualitas hasil tangkapan, sehingga mereka memaksimalkan penggunaan Es untuk menjaga kualitas seperti yang dimaksud.

Rata-rata jumlah penerimaan (Tabel 7) nelayan selama musim puncak penangkapan adalah Rp 323.838.488/bulan. Pe-
Tabel 7 Rata-rata jumlah penerimaan nelayan purse seine di Desa Balimu

\begin{tabular}{clcc}
\hline No & Responden & Jumlah Produksi $(\mathrm{Kg} / \mathrm{bln})$ & Harga ikan $(\mathrm{Kg} / \mathrm{Rp})$ \\
\hline 1 & Rahman & 34.5 & 10.417 \\
2 & Saafaria & 45 & 10.417 \\
3 & Hasanuddin & 14 & 10.417 \\
4 & Kamhar & 42 & 10.417 \\
5 & Saharuddin & 48.6 & 10.417 \\
6 & Landape & 30.6 & 10.417 \\
7 & Sibondo & 19 & 10.417 \\
8 & Musardin & 15 & 10.417 \\
Jumlah & & 248.7 & 83.336 \\
\hline
\end{tabular}

nerimaan tertinggi yakni Rp 506.266.200 sedangkan penerimaan terendah $\mathrm{Rp} 145.838 .000$ /bulan. Pada tingkat harga yang sama penerimaan nelayan ditentukan oleh seberapa banyak hasil tangkapan yang diperoleh. Hasil penelitian ini berbeda dengan Samida and Abdullah (2018), dimana jumlah penerimaaan kapal purse seine di Pelabuhan Perikanan Samudera (PPS) Kendari berkisar antara Rp 91.429.000 sampai Rp 192.780.000/bulan. besar kecilnya penerimaan yang diperoleh nelayan juga sangat ditentukan oleh harga ikan pada saat itu.

Keuntungan nelayan merupakan pendapatan bersih yang diperoleh dikurangi dengan seluruh biaya yang dikeluarkan dalam kegiatan penangkapan. Berdasarkan penelitian yang dilakukan keuntungan nelayan purse seine di Desa Balimu dapat dilihat pada Tabel 8 . Berdasarkan Tabel 8, keuntungan yang diperoleh nelayan purse seine selama musim puncak penangkapan berbedabeda. Keuntungan tertinggi diperoleh nelayan sebesar Rp 446.762.629/bulan, sedangkan keuntungan terendah $\mathrm{Rp}$ $122.081 .056 /$ bulan. Rata-rata keuntungan nelayan purse seine di Desa Balimu adalah Rp 277.263.939 /bulan.

Asumsi yang dibangun dalam analisis cash flow kegiatan usaha penangkapan nelayan purse seine (Gambar 3) di Desa Balimu adalah sebagai berikut : 
Tabel 8 Rata-rata jumlah keuntungan nelayan purse seine di Desa Balimu

\begin{tabular}{ccccc}
\hline No & Responden & Penerimaan (Rp/bulan) & Total Biaya (Rp/bulan) & Keuntungan (Rp/bulan) \\
\hline 1 & Rahman & 359.386 .500 & 20.167 .956 & 339.218 .544 \\
2 & Saafaria & 468.765 .000 & 61.543 .750 & 407.221 .250 \\
3 & Hasanuddin & 145.838 .000 & 23.756 .944 & 122.081 .056 \\
4 & Kamhar & 437.514 .000 & 81.834 .524 & 355.679 .476 \\
5 & Saharuddin & 506.266 .200 & 59.503 .571 & 446.762 .629 \\
6 & Landape & 318.760 .200 & 42.860 .833 & 275.899 .367 \\
7 & Sibondo & 197.923 .000 & 52.438 .452 & 145.484 .548 \\
8 & Musardin & 156.255 .000 & 30.490 .357 & 125.764 .643 \\
Jumlah & & 372.596 .389 & 2.218 .111 .511 \\
Rata-Rata & & 46.590 .707 .900 & 46.574 .549 & 277.263 .939 \\
\hline
\end{tabular}

1. Modal yang digunakan seluruhnya merupakan modal sendiri.

2. Umur proyek/analisis adalah 10 tahun, dimana pada tahun ke-0, usaha dianggap masih mempersiapkan perlengkapan penangkapan dan perizinan sehingga belum memperoleh penerimaan. Tahun ke-1 usaha penangkapan suda mulai dijalankan

3. Kegiatan penangkapan dilakukan sepanjang tahun, meliputi :

- Musim puncak (3 bulan) antara 15 - 23 trip /bulan

- Musim sedang (4 bulan) antara 7 - 11 trip /bulan

- Musim paceklik (5 bulan) antara 4 - 6 trip /bulan

4. Suku bunga yang digunakan (discount factor) adalah $15 \%$ dianggap suku bunga yang berlaku saat ini.

5. Ditahun ke-3 hasil tangkapan dianggap mengalami penurunan sebesar $1 \%$ setiap tahun.

6. Biaya operasional diasumsikan mengalami kenaikan sebesar $2 \%$ setiap tahun.

Berdasakan asumsi di atas, maka diperoleh hasil analisis finansial usaha perikanan tangkap nelayan purse seine di Desa Balimu sebagaimana dapat dilihat pada Tabel 9.

$\mathrm{R} / \mathrm{C}$ rasio merupakan metode analisis untuk mengukur kelayakan usaha de- ngan menggunakan rasio penerimaan (revenue) dan biaya (cost). Analisis kelayakan usaha digunakan untuk mengukur tingkat pengembalian usaha dalam menerapkan suatu teknologi. Soekartawi (1989) menyatakan bahwa semakin besar nilai $\mathrm{R} / \mathrm{C}$ rasio maka akan semakin besar pula penerimaan usaha yang diperoleh untuk setiap rupiah biaya yang dikeluarkan. Kegiatan usaha yang dikategorikan layak jika memiliki nilai $\mathrm{R} / \mathrm{C}$ rasio $>1$, artinya setiap tambahan biaya yang dikeluarkan akan menghasilkan tambahan penerimaan yang lebih besar dari pada tambahan biaya atau secara sederhana kegiatan usaha menguntungkan. Sebaliknya dikategorikan tidak layak jika memiliki nilai $\mathrm{R} / \mathrm{C}$ rasio $<1$ yang berarti untuk setiap tambahan biaya yang dikeluarkan akan menghasilkan tambahan biaya atau kegiatan usaha merugikan. Sedangkan untuk kegiatan usahatani yang memiliki nilai $\mathrm{R} / \mathrm{C}$ rasio $=1$ berarti kegiatan usaha berada pada keuntungan normal (normal profit).

Berdasarkan hasil analisis yang dilakukan maka diperoleh nilai $\mathrm{R} / \mathrm{C}$ rasio sebesar 6,10 yang bermakna bahwa setiap biaya yang dikeluarkan sebesar Rp1 akan memperoleh penerimaan nelayan sebesar Rp6,10. Dengan demikian usaha penangkapan yang dilakukan oleh 
Tabel 9 Kelayakan Finansial usaha nelayan purse seine di Desa Balimu

\begin{tabular}{lcc}
\hline Aspek Kelayakan Finansial & Nilai & Keterangan \\
\hline Net Present Value (NPV)(Rp) & 4.021 .035 .338 & $>0$ (layak) \\
Net Benefit Cost Ratio (Net B/C) & 6,63 & Manfaat yang diterima 6,63 kali dari biaya yang dikeluarkan (layak) \\
R/C rasio & 6,10 & Setiap biaya yang dikeluarkan Rp1 akan menghasilkan penerimaan Rp6,10 = menguntungkan (layak) \\
IRR & 2,87 & $>$ Suku bunga 15\% (layak) \\
PbP (Thn) & 0,85 & Jangka waktu pengembalian modal usaha 0 tahun, 8 bulan, 5 hari (layak) \\
ROI $(\%)$ & 2,31 & Usaha nelayan mendapatkan laba bersih sebesar 2,31\% dari total aset yang dimiliki (layak) \\
\hline
\end{tabular}

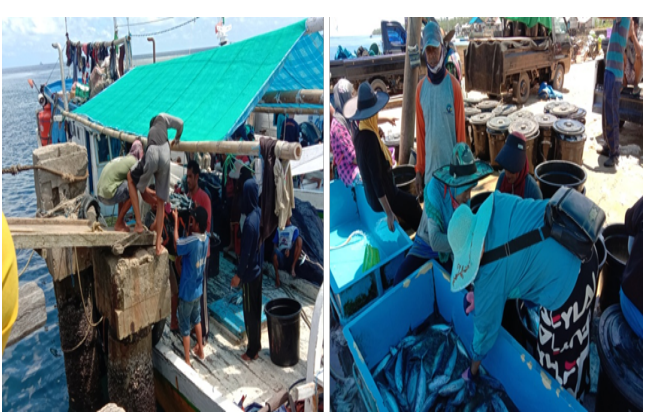

Gambar 3 Aktivitas pendaratan ikan di pelabuhan rakyat Desa Balimu

nelayan purse seine di Desa Balimu menguntungkan dan layak untuk dijalankan.

Menurut Wijayanto et al. (2013), adalah periode yang diperlukan untuk menutup kembali pengeluaran investasi (initial cash investment). Sedangkan menurut Riyanto (2004) Payback period adalah suatu periode yang diperlukan untuk dapat menutup kembali pengeluaran investasi dengan menggunakan proceeds atau aliran kas netto (net cash flows).

Berdasarkan hasil analisis yang dilakukan, maka diperoleh nilai PbP sebesar 0,85 tahun. Hal tersebut bermakna bahwa jangka waktu pengembalian dari investasi yang ditanamkan sangat cepat yakni 8 bulan 5 hari. Menurut Kasmir et al. (2015), jangka waktu (periode) pengembalian investasi suatu usaha atau proyek terdiri dari tiga yakni : (a) nilai payback period kurang dari 3 tahun kategori pengembalian cepat; (b) 3 - 5 tahun kategori pengembalian sedang; dan (c) lebih dari 5 tahun ka- tegori pengembalian lambat. Kegiatan penangkapan yang dilakukan oleh nelayan purse seine di Desa Balimu sepanjang tahun menyebabkan waktu pengembalian dari modal yang diinvestasikan relatif lebih cepat ( $<1$ tahun).

Perhitungan ROI dibutuhkan mengetahui tentang ukuran keuntungan atau kerugian yang diperoleh dari investasi yang ditanamkan. ROI juga digunakan untuk mengevaluasi semua kegiatan operasional terhadap tingkat pengembalian investasi tersebut. Return of Investment adalah rasio profitabilitas yang mengukur efisiensi sebuah investasi dengan membandingkan laba bersih dengan total biaya atau modal yang diinvestasikan. Ini artinya, ROI yang bernilai positif menunjukkan keuntungan, sedangkan jika bernilai negatif menunjukkan kerugian. Rasio ROI sendiri biasanya diukur dalam bentuk persentase.

Berdasarkan analisis yang dilakukan, maka diperoleh nilai ROI sebesar 2,31\%, yang bermakna bahwa usaha nelayan purse seine di Desa Balimu memiliki kemampuan untuk menghasilkan laba dari total aset yang dimiliki sebesar 2,31\% . Dengan demikian usaha yang dijalankan layak untuk dilanjutkan.

Menurut Kho (2018), Net Present Value adalah selisih antara nilai sekarang dari arus kas yang masuk dengan nilai sekarang dari arus kas yang keluar pada periode waktu tertentu. NPV 
atau Net Present Value ini mengestimasikan nilai sekarang pada suatu proyek, aset ataupun investasi berdasarkan arus kas masuk yang diharapkan pada masa depan dan arus kas keluar yang disesuaikan dengan suku bunga dan harga pembelian awal. Net Pressent Value menggunakan harga pembelian awal dan nilai waktu uang (time value of money) untuk menghitung nilai suatu aset. Dengan demikian, dapat dikatakan bahwa NPV adalah Nilai Sekarang dari Aset yang dikurangi dengan harga pembelian awal Jika NPV >0, maka usaha dinyatakan layak untuk dilanjutkan, jika $\mathrm{NPV}=0$, maka usaha hanya kembali modal, dan jika NPV $<0$, usaha dinyatakan tidak layak untuk dilanjutkan.

Berdasarkan hasil analisis yang dilakukan, maka diperoleh nilai NPV sebesar Rp 4.021.035.338 (>1). Dengan demikian dapat dikatakan bahwa usaha nelayan purse seine di Desa Balimu layak untuk dilanjutkan.

Menurut Kadariah and Gray (1999), Net benefit-cost ratio adalah perbandingan antara jumlah kini (present value total) dari keuntungan bersih pada tahun-tahun dimana keuntungan bersih bernilai positif dengan keuntungan bersih yang bernilai negatif. Kriteria Net B/C rasio adalah jika net $\mathrm{B} / \mathrm{C}>1$, berarti usaha layak dijalankan; jika net $\mathrm{B} / \mathrm{C}=1$, berarti usaha impas, dan jika net $\mathrm{B} / \mathrm{C}<1$, berarti usaha tidak layak dijalankan. Berdasarkan hasil analisis yang dilakukan, diperoleh nilai Net B/C Rasio sebesar 6,63 yang bermakna bahwa usaha nelayan purse seine di Desa Balimu saat ini memiliki manfaat sebesar 6,63 kali lipat dari biaya yang dikeluarkan. Dengan demikian usaha tersebut dapat dinyatakan layak. Penelitian serupa yang dilakukan oleh Pujianto et al. (2013), dimana hasil penelitian menunjukkan nilai R/C Rasio 1,71, payback period 2,22 tahun, NPV sebesar Rp 454.423.108, dan IRR sebesar 38,56\% dengan discount factor $14 \%$, dengan kesimpulan usaha mini purse seine di PPI Ujungbatu Kabupaten Jepara layak secara finansial. Selanjutnya penelitian yang dilakukan oleh Nugraha et al. (2014) tentang analisis kelayakan finansial usaha perikanan tangkap mini purse seine di Pelabuhan Perikanan Pantai (PPP) Tasik Agung Kabupaten Rembang, dimana hasil penelitian adalah nilai NPV untuk kapal ukuran 21-30 GT yakni Rp 1.365.636.044, IRR sebesar 28\%, payback period 2,13 tahun, dan nilai $\mathrm{B} / \mathrm{C}$ rasio 1,28 . Jika dibandingkan dengan penelitian tersebut, periode pengembalian biaya investasi nelayan purse seine di Desa Balimu lebih cepat dibandingkan dengan nelayan purse seine yang berada di PPI Ujungbatu Kabupaten Jepara.

\section{SIMPULAN}

Berdasarkan hasil penelitian yang dilakukan, maka dapat disimpulan bahwa secara finansial kegiatan usaha penangkapan nelayan purse seine di Desa Balimu Kecamatan Lasalimu Selatan layak untuk dijalankan. Perlu untuk dilakukan penelitian untuk melihat jalur pemasaran apa saja yang terbentuk, margin pemasaran pada setiap lembaga pemasaran dan farmer share dari kegiatan nelayan purse seine di Desa Balimu Kecamatan Lasalimu Selatan.

Acknowledgements : Ucapan terimakasih kami yang sebesar-besarnya kepada Lembaga Penelitian dan Pengabdian Kepada Masyarakat (LPPM) Universitas Halu Oleo yang telah memberikan kepercayaan mapun pendanaan, sehingga penelitian internal UHO dapat terlakasana dengan baik. Ucapan terimakasih juga kami 
sampaikan kepada pimpinan dalam hal ini Rektor Universitas Halu Oleo, dan pimpinan Fakultas Perikanan dan Ilmu Kelautan Universitas Halu Oleo atas kesempatan yang diberikan kepada kami untuk melakukan penelitian ini. Ucapan terimkasih juga kami haturkan masyarakat Desa Balimu dan semua pihak-pihak yang membantu terlaksanya penelitian ini.

\section{Pustaka}

Arikunto, S. (2010). Prosedur Penelitian Suatu Pendekatan Praktik. Rineka Cipta Jakarta.

Kadariah, L. K. and Gray, C. (1999). Pengantar evaluasi proyek. Jakarta: Fakultas Ekonomi Universitas Indonesia, 181.

Kasmir, S. et al. (2015). Studi Kelayakan Bisnis: Edisi Revisi. Prenada Media.

Kho, B. (2018). Pengertian rasio perputaran total aset dan rumusnya.

Nugraha, A., Wibowo, B. A., et al. (2014). Analisis finansial usaha perikanan tangkap mini purse seine di pelabuhan perikanan pantai (ppp) tasik agung kabupaten rembang. Journal of Fisheries Resources Utilization Management and Technology, 3(4):56-65.

Pujianto, Boesono, H., and Wijayanto, D. (2013). Analisis kelayakan usaha aspek finansial penangkapan mini purse seine dengan ukuran jaring yang berbeda di ppi ujungbatu kabupaten jepara. Journal of Fisheries Resources Utilization Management and Technology, 2(2):124-133.

Rahardja, P. and Manurung, M. (2008). Pengantar ilmu ekonomi. Fakultas Ekonomi Universitas Indonesia. Jakarta, 189.

Riyanto, B. (2004). Dasar-dasar pembelanjaan perusahaan, yogyakarta: Edisi keempat. Cetakan Kedelapan. BPFE.

Samida, A. and Abdullah, L. (2018). Analisis pendapatan usaha purse seine di pelabuhan perikanan samudera (pps) kendari dan faktor-faktor yang mempengaruhinya. Jurnal Manajemen Sumber Daya Perairan, 3(2):125-134.

Soekartawi (1989). Prinsip dasar manajemen pemasaran hasil-hasil pertanian: teori dan aplikasinya. Rajawali.

Sugiyono (2001). Metode Penelitian. CV Alfa Beta.
Syamsuddin and Damayanti (2011). Metode Penelitian Pendidikan Bahasa. Remaja Rosdakarya.

Umar, H. (2013). Metode penelitian untuk skripsi dan tesis bisnis.

Wijayanto, D., SPi, M., et al. (2013). Pengantar manajemen. Gramedia Pustaka Utama.

Kontribusi: Sarifin, A: Mengambil data Lapangan, menulis manuscript; Sidiq, A: Mengambil data Lapangan, analisis data, dan pembahasan; Unga, W. O. H: Merangkum dan analisis data; Aminur: Analisis Data dan menulis pembahasan 